\title{
An Analysis of Psychiatrists, Their Patients' Suicides, and Aftermath
}

\author{
Gopala Sarma Poduri
}

\begin{abstract}
Background: Suicides among psychiatric patients are common. Most of the psychiatrists during their professional life will see at least one patient of theirs committing suicide. It can have distressing effects on them.

Aim and objective: To find the personal and professional details of psychiatrists, suicides of patients under their care, and their effects.

Design: Contacting randomized representative sample of psychiatrists active in clinical patient care by online and offline communication methods. Participants: Representative sample of 143 psychiatric postgraduates (PGs) and psychiatrists in India, who are in active practice of the profession. Main outcome measures: Personal and professional details of psychiatrists, and details of the suicide of the patient under their care, effects, and coping mechanisms.

Results: Out of a total of 143 responses- $62 \%$ of male and $38 \%$ of female- $29.4 \%$ of responders reported at least one patient under their treatment committing suicide, with an average of $12.8 \%$ of suicides for psychiatrists having such experience. Senior psychiatrists were overrepresented by age-wise and experience-wise. The commonest diagnosis was depression, and the method adopted was hanging. Suicide of the patient under treatment affected $40.5 \%$ of treating psychiatrists in both personal and professional life. And $26.2 \%$ had no impact on either personal or professional life; $33.3 \%$ of responders reported that the suicide of the patient had an impact on either personal or professional life. Most of them felt the suicide was predictable, preventable, and the training they had was adequate. More than half were apprehensive about litigation. Due to the suicide of patients, six psychiatrists considered taking early retirement.

Conclusion: There is a need for preparing newer and younger psychiatrists to face the ordeal of the patient under treatment committing suicide. Keywords: Effect, Patient suicide, Personal, Professional, Psychiatrist.

Indian Journal of Private Psychiatry (2021): 10.5005/jp-journals-10067-0079
\end{abstract}

\section{INTRODUCTION}

Death is not a stranger to doctors. Emergency, critical care, terminal care, and oncology doctors stare at death almost in every case. Unlike them, for a psychiatrist, it is not a daily affair and not that common. This difference leaves the treating doctors with different reactions. For example, burnout is more common among doctors of the above departments than psychiatrists. Death of a patient by suicide-an irreversible, irrevocable, premature, avoidable, and untimely caseation of life by self-is generally the only death that psychiatrists face in their clinical practice. It has consequences on the treating psychiatrist.

There were 230,314 suicide deaths in India in 2016 alone. ${ }^{1}$ The officially reported suicides for the previous 10-year period of 2006 2015 were 1,298,634. ${ }^{2}$ The real rate of suicide will be higher than the official estimates due to a variety of reasons. As the professional relationship in psychiatry is different, unique, and longer, suicide by patients has a substantial emotional and professional effect on the concerned psychiatrist. A considerable number of psychiatrists at one time or other will face suicide by a patient under their treatment in their professional career. It was estimated that around $68-80 \%$ of psychiatrists ${ }^{3}$ and $47 \%$ of trainees lost patients to suicide. ${ }^{4}$ Psychiatrists from Ireland experienced an impact either on their personal $(87 \%)$ or on their professional life (88\%) following patient suicide in their career. ${ }^{5}$

There were reports from other countries about various aspects of patient suicide and treating medical personnel, psychiatrists, and trainees. ${ }^{3-16}$

Indian psychiatric literature is silent on this important issue. There is a need for the evaluation of this issue for preparing the
Department of Psychiatry, Yashoda Super-speciality Hospital, Hyderabad, Telangana, India

Corresponding Author: Gopala Sarma Poduri, Department of Psychiatry, Yashoda Super-speciality Hospital, Hyderabad, Telangana, India, Phone: +91 8179136510, e-mail: gopalasarmapoduri@hotmail.com

How to cite this article: Poduri GS. An Analysis of Psychiatrists, Their Patients'Suicides, and Aftermath. Ind J Priv Psychiatry 2021;15(1):27-31. Source of support: Nil

Conflict of interest: None

residents to face such an eventuality. Keeping this in view, a survey was undertaken to find out the details of Indian psychiatrists with a patient history of suicides, details of such suicides, their effect, and coping mechanisms.

\section{Materials and Methods}

After literature review and review of the questionnaires used, discussion with other experienced doctors, and taking into consideration the personal experience, a questionnaire was prepared. This was tested on some doctors and found to be satisfactory. The questionnaire consisted of three main items: 1. Personal details-gender, age, years in the profession, years as consultant, qualification, setup, and common cases seen; 2. Suicide details (that had a major impact on the psychiatrist) total number of suicides by their patients under treatment in their service, psychiatrists status at that time, and patient status, such 
as gender, age, method, diagnosis, prior history, place of suicide, predictability, preventability, adequacy of training to face the suicide of the patient, and apprehension about litigation; and 3. Effects-personal, professional, leave from duty, and the way adverse effects were tackled. An open-ended comment relating to the impact of patient suicide on treating psychiatrists was the last item. Almost all the personal, professional impacts, and support systems used were of a 5-point Likert scale.

The questionnaire was sent to the randomized representative psychiatrists working in different settings from different regions of India from the membership data of various psychiatric societies by online and offline communication methods with a reminder in the absence of a response. Further help of colleagues, representatives from the area, and a couple of conferences were resorted to. The data were analyzed by basic statistics. The data were analysed by basic statistics including Chi square. The core concepts among comments were computed in the last comment question. The hospital ethics committee's approval was taken.

\section{Results}

A total of $143-62 \%$ of male and $38 \%$ of female-responses were found to be fit for the analysis. The response rate was $38.9 \%$. Forty-two responders (29.4\%) reported at least one of their patients committed suicide. A total of 538 suicides were reported with an average of $12.8 \%$ of suicides per psychiatrist having such an experience and $3.8 \%$ of total responding psychiatrists. Male psychiatrists (39.3\%) reported a significantly higher rate than female psychiatrists (13\%).

Table 1 shows the details of psychiatrists' response that differed significantly.

There were no gender differences in the following, so they were clubbed together. Seventy-two percent were outpatient (OP) cases, maximum was $74 \%$ of male, and $41 \%$ were young below 30 years of age. The commonest method adopted was hanging (50\%) followed by run over by train and bus (16.6\%). The commonest diagnosis was depression (39.6\%) followed by schizophrenia (28.3\%). Interestingly, all the cases reported by female psychiatrists were depression; $47.5 \%$ had a prior history of deliberate self-harm. Most of the suicides were committed (52.7\%) at the house.

With hindsight, most of the psychiatrists felt the referred suicide was predictable (71\%), preventable (73\%), and felt the training they had was adequate (87\%) to face them. Fifty-nine percent were apprehensive about litigation-police complaint, inquiry, and complaint to Medical Council of India.

Only one abstained or took leave from duty following the suicide of the patient, while three thought of early retirement. Nearly, $26.2 \%$ had no impact on either personal or professional life, whereas $33.3 \%$ of responders reported that the suicide of the patient had an impact on either personal or professional life, and $40.5 \%$ had an impact on both personal and professional life. And $64.4 \%$ reported changes in professional practice. The commonest personal effect was surprise (10.2\%) followed by grief $(9.5 \%)$. The commonest professional impact of patient suicide on the treating psychiatrist was more conscious of risk (21.8\%) followed by overcautious and admitting on slightest risk (15.8\%).

Colleagues (29\%) were the main support sources followed by family (24\%) who helped psychiatrists to face the aftermath of the patient suicide.

Nearly half of them have answered the open-ended response to suicide, and the common response was it was traumatic, and it made them to be more cautious and overcautious.
Table 1: Details of psychiatrists' response that differed significantly

\begin{tabular}{|c|c|c|c|c|}
\hline \multirow[b]{2}{*}{ Parameter } & \multicolumn{2}{|c|}{$\begin{array}{c}\text { With a patient } \\
\text { committed suicide }(42)^{*}\end{array}$} & \multicolumn{2}{|c|}{$\begin{array}{l}\text { No patient committed } \\
\text { suicide }(101)^{*}\end{array}$} \\
\hline & Male & Female & Male & Female \\
\hline Gender $^{a}$ & 35 & 7 & 54 & 47 \\
\hline \multicolumn{5}{|l|}{$\mathrm{Age}^{\mathrm{b}}$} \\
\hline Mean age & 53.8 & 48.3 & 38.1 & 38.6 \\
\hline Up to 30 years & 1 & 2 & 7 & 4 \\
\hline Up to 40 years & 7 & 0 & 29 & 21 \\
\hline Up to 50 years & 6 & 2 & 14 & 20 \\
\hline Up to 60 years & 7 & 0 & 3 & 1 \\
\hline Up to 70 years & 8 & 2 & 1 & 1 \\
\hline Above 70 years & 5 & 1 & 0 & 0 \\
\hline \multicolumn{5}{|c|}{ Experience in psychiatry (years) ${ }^{c}$} \\
\hline Up to10 years & 5 & 2 & 36 & 23 \\
\hline Up to 20 years & 8 & 1 & 12 & 22 \\
\hline Up to 30 years & 6 & 1 & 4 & 2 \\
\hline Up to 40 years & 12 & 2 & 2 & 0 \\
\hline Above 40 years & 3 & 1 & 0 & 0 \\
\hline \multicolumn{5}{|c|}{ Independent consultant ${ }^{d}$} \\
\hline Up to 10 years & 5 & 0 & 16 & 11 \\
\hline Up to 20 years & 9 & 1 & 9 & 8 \\
\hline Up to 30 years & 9 & 2 & 3 & 2 \\
\hline Up to 40 years & 9 & 3 & 0 & 0 \\
\hline Above 40 years & 3 & 1 & 0 & 0 \\
\hline \multicolumn{5}{|c|}{ Qualification in psychiatry ${ }^{\mathrm{e}}$} \\
\hline Degree & 16 & 4 & 42 & 35 \\
\hline Diploma & 6 & 1 & 4 & 0 \\
\hline More than one & 3 & 0 & 7 & 10 \\
\hline PG resident & 10 & 2 & 0 & 2 \\
\hline \multicolumn{5}{|l|}{ Service ${ }^{f}$} \\
\hline GOVT. & 7 & 3 & 6 & 15 \\
\hline PVT. & 11 & 3 & 25 & 14 \\
\hline PVT. PSY. & 10 & 1 & 20 & 17 \\
\hline ВОТН & 5 & 0 & 1 & 0 \\
\hline
\end{tabular}

*Due to the nonavailability of data, total may not tally in some parameters. $\mathrm{a}, \mathrm{b}, \mathrm{c}, \mathrm{d}, \mathrm{e}, \mathrm{e} \leq 0.001 ; \mathrm{f} p=0.01$

\section{Discussion}

The response rate was better compared with the reported surveys from other countries like Switzerland, Flemish psychiatrists (Belgium), United Kingdom, and Italy, but less than other countries as shown in the above Table 2 . In comparison with two recent India studies, the response rate is less. ${ }^{17,18}$ This may be due to the feeling that this will not occur to me and, hence ignoring the request. Further, psychiatrists are known to be poor responders for surveys, in general.

Keeping in view the number of suicides in the country mentioned earlier, the total number of patient suicides encountered by treating psychiatrists - 538, obtained in this study - is not very high. The result that $70.6 \%$ of psychiatrists did not have even a single patient under their care committing suicide is in contrast with other reported studies (Table 2). So, the possibility of very low/nil number of patients' suicide for those with less than 10 years in psychiatry and mostly in private sector consultation coupled with the result 
Table 2: Sample size, response rate and Effect on treating psychiatrist

\begin{tabular}{|c|c|c|c|c|c|c|}
\hline \multirow[b]{2}{*}{ SI. No } & \multirow[b]{2}{*}{ Authors } & \multirow[b]{2}{*}{ Title/journal } & \multirow{2}{*}{$\begin{array}{l}\text { Country/sample } \\
\text { size/response } \\
\text { rate (\%) }\end{array}$} & \multirow{2}{*}{$\begin{array}{l}\text { Rate (patient } \\
\text { suicides reported by } \\
\text { participants) (\%) }\end{array}$} & \multicolumn{2}{|c|}{ Effect on treating psychiatrist } \\
\hline & & & & & Personal (\%) & Professional (\%) \\
\hline 1 & $\begin{array}{l}\text { Alexander DA, } \\
\text { Thompson SK, } \\
\text { Gray M, et al. }\end{array}$ & $\begin{array}{l}\text { Suicide by patients: Questionnaire study } \\
\text { of its effect on consultant psychiatrists. } \\
\text { BMJ 2000;320(7249):1571-1574. }\end{array}$ & $\begin{array}{l}\text { Scotland } \\
247 \\
78\end{array}$ & 68 & 33 & 42 \\
\hline 2 & $\begin{array}{l}\text { Chemtob CM, } \\
\text { Hamada SR, } \\
\text { Bauer G, et al. }\end{array}$ & $\begin{array}{l}\text { Patients' suicides: Frequency and } \\
\text { impact on psychiatrists. Am J Psychiatry } \\
\text { 1988;145(2):224-228. }\end{array}$ & $\begin{array}{l}\text { US } \\
269 \\
46\end{array}$ & 51 & 50 & 50 \\
\hline 3 & $\begin{array}{l}\text { Lamders A, } \\
\text { O'Brien S, } \\
\text { Darra P. }\end{array}$ & $\begin{array}{l}\text { Impact of patient suicide on consultant } \\
\text { psychiatrists in Ireland. Psychiatrist } \\
\text { 2010;34(4):136-140. }\end{array}$ & $\begin{array}{l}\text { Ireland } \\
182 \\
61\end{array}$ & 80 & 87 & 88 \\
\hline 4 & $\begin{array}{l}\text { Ruskin R, } \\
\text { Sakinofsky I, } \\
\text { Bagby R, et al. }\end{array}$ & $\begin{array}{l}\text { Impact of patient suicide on psychiatrists } \\
\text { and psychiatric trainees. Acad Psychiatry } \\
2004 ; 28(2): 104-110 .\end{array}$ & $\begin{array}{l}\text { Canada } \\
295 \\
48\end{array}$ & 50 & 25 & - \\
\hline 5 & $\begin{array}{l}\text { Thomyangkoon } \mathrm{P} \text {, } \\
\text { Leenaars } \mathrm{A} \text {. }\end{array}$ & $\begin{array}{l}\text { Impact of death by suicide of patients } \\
\text { on Thai psychiatrists. Suicide Life Threat } \\
\text { Behav } 2008 ; 38(6): 728-740 \text {. }\end{array}$ & $\begin{array}{l}\text { Thailand. } \\
163 \\
52.18\end{array}$ & 56.3 & 52.7 & 74.5 \\
\hline 6 & $\begin{array}{l}\text { Courtenay K, } \\
\text { Stephens J. }\end{array}$ & $\begin{array}{l}\text { The experience of patient suicide among } \\
\text { trainees in psychiatry. Psychiatr Bull } \\
2001 ; 25(2): 51-52 \text {. }\end{array}$ & $\begin{array}{l}\text { Southern } \\
\text { Thames region } \\
\text { of UK } \\
203 \\
51\end{array}$ & 54 & 75 & 68 \\
\hline 7 & $\begin{array}{l}\text { Dransart DAC, } \\
\text { Gutjahr E, Gulfi A, } \\
\text { et al. }\end{array}$ & $\begin{array}{l}\text { Patient suicide in institutions: Emotional } \\
\text { responses and traumatic impact on } \\
\text { Swiss mental health professionals. Death } \\
\text { Stud 2013:38(1-5):315-321. }\end{array}$ & $\begin{array}{l}\text { Switzerland } \\
314 \\
34\end{array}$ & 70 & Low & Low \\
\hline 8 & $\begin{array}{l}\text { Scocco P, } \\
\text { Toffol E, } \\
\text { Pilotto E, et al. }\end{array}$ & $\begin{array}{l}\text { Psychiatrists' emotional reactions to } \\
\text { patient suicidal behavior. J Psychiatr } \\
\text { Pract 2012;18(2):94-108. }\end{array}$ & $\begin{array}{l}\text { Italy } \\
174 \\
34\end{array}$ & 32.4 & 100 & - \\
\hline 9 & $\begin{array}{l}\text { Gibbons R, Brand F, } \\
\text { Carbonnier A, et al. }\end{array}$ & $\begin{array}{l}\text { Effects of patient suicide on } \\
\text { psychiatrists: Survey of experiences } \\
\text { and support required. B J Psych Bull } \\
\text { 2019;43(5):236-241. }\end{array}$ & $\begin{array}{l}\text { UK } \\
174 \\
34\end{array}$ & 80.5 & 69 & 90 \\
\hline 10 & $\begin{array}{l}\text { Rothes IA, } \\
\text { Scheerder G, } \\
\text { Audenhove } \mathrm{CV} \text {, et al. }\end{array}$ & $\begin{array}{l}\text { Patient suicide: The experience of } \\
\text { Flemish psychiatrists. Suicide Life Threat } \\
\text { Behav 2013;43(4):379-394. }\end{array}$ & $\begin{array}{l}\text { Flemish Region } \\
\text { of Kingdom of } \\
\text { Belgium } \\
584 \\
18\end{array}$ & 91.6 & 47 & 45 \\
\hline
\end{tabular}

that seniors, in both age and experience, are overrepresented in the group that had at least one patient suicide may be due to poor follow-up and feedback from attendants. Another most probable and plausible reason could be poor/negligible number of patients seen during the training period, a common observation, and allegation against most of the newer, nongovernmental medical college hospitals. Coupled with this, a dearth of experienced teaching staff in both government and private colleges, which prompted the ministry to permit overseas and private practitioners to act as guest faculty on payment, might be another factor. Another reason could be referring almost every suicidogenic patient to other centers to avoid facing it, which can be demoralizing and affects practice.

Participants with the degree and more than one qualification were more in the group with no patient suicide. This coupled with less experience in this group is an indicator of the explosion of institutions producing postgraduates (PGs). This may further be aggravated in the future due to further recent sanctioning of more PG seats.
Almost all cases resorted to hard core, violent methods like hanging, run over by a train, leaving not much chance for rescue, and revival. This shows, apart from the determination of the patient for ending life, an urban predominance/bias as chemical methods like ingestion of pesticides, etc., is common in rural areas. As most of the agricultural operations, including cultivable land shrinking, rapid urbanization, and almost all psychiatric facilities being in urban areas, use of hard-core methods are understandable. Further, hanging does not require much money and is easy, available all the time, almost instantaneous, and most of the time irreversible. Coupled with this, nearly half had a previous history and attempted suicide at home. Some of these factors might have helped the psychiatrist to face the situation by consoling themselves that it is unavoidable, nothing could have been done, and there is no need to blame themselves, feel bad, and be sad. This can explain a very low, almost negligible, number of psychiatrist wanting to change or quit the profession unlike in some other studies.

The fact that only three cases of addictions, schizophrenia far less, depression, and bipolar illness, accounting for the maximum 
suicides is a reflection on the diagnostic practice of the times. Even though suicides might have occurred and were spread over a long time, viewing the past from the present time might have influenced the labeling. The present finding is in variance to other reports that were much earlier when the diagnosis of schizophrenia was almost the norm. ${ }^{12}$

The finding that in hindsight most felt it was predictable and preventable can lead to self-blame and guilt. ${ }^{3}$ Only less than $10 \%$ felt guilty in the present survey. Paradoxically, the same thinking as in coping with hanging might have helped most of them in not having guilt feelings. The overwhelming feeling that the training was adequate is encouraging, but this must be tested in the majority (70.6\%) who did not face such a situation.

The rate of personal and/or professional effect is comparable but toward the lower end as shown in Table 2. This not-so-high personal impact may be explained as due to cultural and religious philosophy of destiny and hence no responsibility of the treating psychiatrist.

In the present study, resorting to colleagues was the mode of tackling the consequences. This agrees with other studies. This is understandable because the colleagues might have faced such a situation, and they are most likely to face such a situation in the future if not faced already. This causes empathy and hence is best suited to support. In India, generally, reviews are not held in the department for suicide deaths.

The finding of the present survey was that the commonest professional effect was heightened awareness of risk agreed with most of the surveys.

Women psychiatrists faced patient suicide grossly less than their male colleagues. This can be explained by the fact that the increase in their number is relative of recent origin and hence comes under the category of lesser experience and consequential low rate as mentioned in the beginning. This contrasts with other reports where some gender differs in responses, with women reporting more sense of responsibility for the deaths and a greater effect on their clinical confidence. ${ }^{14}$

The professional reactions and changes in working practicesmore conscious of risk, overcautious, and admitting on slightest risk; advising for second opinion; and referring and referring highrisk patients to higher centers-increase the cost to the patient, cause apprehension to the caregivers, and are a form of defensive medical practice. In the future, this tendency is likely to increase due to an increase in the number of laws, lawyers, and consequent litigation and consumer cases. Increased awareness, availability of all information about every conceivable and unconceivable thing at the click of a mouse, and increased competition among professionals for survival will all in the likelihood may aggravate the situation further. Support of colleagues will be helpful here. The present study did show evidence for this. More than half of the responders expressed fear. With the quantum jump in the number of professionals, laws, higher compensation in cases of patient death due to maltreatment, professional negligence-real or perceived, awareness of public about human rights to criminal laws, and increase in laws relating to the medical profession, the fear of litigation after the suicide of a patient is bound to increase. Thus, there is a need for some mechanism to be incorporated in the training of the new psychiatrist to face them.

The negligible number of participants thinking of early retirement and change of profession following patient suicide was in stark contrast to $15 \%$ of Scotland psychiatrists ${ }^{3}$ and $27 \%$ in another study. ${ }^{4}$ One reason for this could be early retirement, and change of profession is alien concepts in the thinking and practice of the nation as evidenced in sports, politics, professions, industry, etc.

The present study adds to the literature. It brings out the low rate of patient suicide per psychiatrist in India and less severe effects on psychiatrists. It highlights the possibility of inadequate training due to paucity of patients and trained teachers, an issue that needs to be investigated for the future of psychiatry. Methodology and sample size should not be the reasons for rejecting the conclusions drawn taking into consideration the nature of the study, representativeness of the sample, and similarity of the questionnaire used by other reviewed studies. The present study is the first survey about this topic among Indian psychiatrists. It has many deficiencies apart from the above, retrospective nature makes it vulnerable for vagaries of timerelated issues like memory distortions and retrospective falsification; the response rate was not high; the survey was based on the high impact of suicide so that other effects might have been buried and some exaggerated; ${ }^{9}$ and suffers from attended drawbacks of self-report of the participants. These results may be taken as indicators and preliminary to be enlarged upon.

\section{Acknowledgments}

Author would like to thank the help rendered by Mr. Manu and Mr. Sridhar of ICON in the survey.

\section{References}

1. Dandona R, Kumar GA, Dhaliwal RS, et al. Gender differentials and state variations in suicide deaths in India: the global burden of disease study 1990-2016. India State-Level Disease Burden Initiative Suicide Collaborators. Lancet Public Health 2018;3:e478-e489. DOI: 10.1016/ S2468-2667(18)30138-52.

2. Available from: http://ncrb.gov.in/StatPublications/ADSI/ PrevPublications.htm

3. Alexander DA, Klein SK, Gray NM, et al. Suicide by patients: questionnaire study of its effect on consultant psychiatrists. BMJ 2000;320(7249):1571-1574. DOI: 10.1136/bmj.320.7249.1571.

4. Dewar I, Eagles J, Klein S, et al. Psychiatric trainees' experiences of, and reactions to, patient suicide. Psychiatr Bull 2000;24(1):20-35. DOI: 10.1192/pb.24.1.20.

5. Lamders A, O'Brien S, Darra P. Impact of patient suicide on consultant psychiatrists in Ireland. Psychiatrist 2010;34(4):136-140. DOI: 10.1192/ pb.bp.109.025312.

6. Chemtob CM, Hamada SR, Bauer G, et al. Patients' suicides: frequency and impact on psychiatrists. Am J Psychiatry 1988;145(2):224-228. DOI: 10.1176/ajp.145.2.224.

7. Courtenay K, Stephens J. The experience of patient suicide among trainees in psychiatry. Psychiatr Bull 2001;25(2):51-52. DOI: 10.1192/ pb.25.2.51.

8. Elizabeth MJC, Kelly P, McCaffrey B. The experience of patient suicide among Irish psychiatrists. Psychiatr Bull 1995;19(1):4-7. DOI: 10.1192/ pb.19.1.4.

9. Da Ponte G, Neves T, Lobo M. Psychiatrist's reactions to patient suicide. Eur Psychiatry 2011;26(1):1611. DOI: 10.1016/S0924-9338(11)73315-6.

10. Murphy PT, Clogher L, van Laar A, et al. The impact of service user's suicide on mental health professionals. Ir J Psychol Med 2019;19:1-11. DOI: 10.1017/ipm.2019.4.

11. Thomyangkoon $P$, Leenaars A. Impact of death by suicide of patients on Thai psychiatrists. Suicide Life Threat Behav 2008;38(6):728-740. DOI: 10.1521/suli.2008.38.6.728.

12. Ruskin R, Sakinofsky I, Bagby RM, et al. Impact of patient suicide on psychiatrists and psychiatric trainees. Acad Psychiatry 2004;28(2):104-110. DOI: 10.1176/appi.ap.28.2.104. 
13. Scocco P, Toffol E, Pilotto E, et al. Psychiatrists' emotional reactions to patient suicidal behavior J Psychiatr Pract 2012;18(2):94-108. DOI: 10.1097/01.pra.0000413275.09305.d5.

14. Gibbons R, Brand F, Carbonnier A, et al. Effects of patient suicide on psychiatrists: survey of experiences and support required. B J Psych Bull 2019;43(5):236-241. DOI: 10.1192/bjb.2019.26.

15. Rothes IA, Scheerder G, Audenhove CV, et al. Patient suicide: the experience of Flemish psychiatrists. Suicide Life Threat Behav 2013;43(4):379-394. DOI: 10.1111/sltb.12024.
16. Dransart DAC, Gutjahr E, Gulfi A, et al. Patient suicide in institutions: emotional responses and traumatic impact on Swiss mental health professionals. Death Stud 2013:38(1-5):315-321. DOI: 10.1080/07481187.2013.766651.

17. Sarma PG. Burnout in Indian psychiatrists. Indian J Psychol Med 2018;40(2):156-160. DOI: 10.4103/IJPSYM.IJPSYM_265_17.

18. Poduri GS. Psychiatrists' perception of continuing medical education (CME). Ind J Priv Psychiatry 2018;12(2):46-49. DOI: 10.5005/ jp-journals-10067-0019. 